DOI https://doi.org/10.36059/978-966-397-237-4-9

Сон C. C., старший викладач кафедри конституційного права Національного університету «Одеська юридична академія», м. Oдеса

\title{
ОСНОВОПОЛОЖНІ ПРИНЦИПИ ТА МЕХАНІЗМ РЕАЛІЗАЦІЇ ПРАВА НА ДОСТУП ДО ПУБЛІЧНОЇ ІНФОРМАЦІЇ
}

Анотація. Розкрито право на доступ до публічної інформації як основне право людини та важливий чинник розвитку демократії та реалізації основних прав людини. Здійснено аналіз закономірностей формування та розвитку національного та міжнародного законодавства щодо доступу до публічної інформації. Виокремлено й охарактеризовано покоління національних законів, що регулюють цю сферу відносин. На підставі аналізу законодавства, що регулює питання доступу до публічної інформації, виокремлено підходи, відповідно до яких визначається місце права доступу до публічної інформації у системі прав людини: 1) право на доступ до публічної інформації виникає зі свободи преси (Швеція, інші скандинавські держави, Сполучені Штати Америки); 2) право на доступ до публічної інформації базується на свободі вираження думки та прозорості діяльності державних органів. Виявлено чинники, що впливають на постійний розвиток і трансформацію права доступу до публічної інформації. Це право покладає на держави позитивне зобов'язання визнавати право доступу до публічної інформації $i$ розробляти зручні для користувачів системи, що забезпечують практичний доступ до інформації як шляхом відповіді на запити щодо інформації, так і шляхом завчасного їі розкриття. Залежно від рівня правової регламентації виділено два основні інституційні механізми його забезпечення: 1) міжнародний (зокрема, міжнародний регіональний); 2) національний.

Наголошено, що суцільна цифровізація та нові технології забезпечують вільний та легкий доступ до значної кількості документів, однак це не означає, що немає проблем із забезпеченням доступу до публічної інформації, розпорядниками якої є державні органи, зокрема, поширена практика їі надмірного засекречування, встановлення значних зборів та строків їі надання тощо. 


\section{Вступ}

Суттєве значення у цифрову епоху має інформація, яка стала визначальним елементом еволюції сучасного суспільства, а право на доступ до неї $\epsilon$ важливим для розвитку демократії та реалізації основних прав людини. Інформатизацію суспільних відносин, їх цифровізацію розглядають як один із напрямів розвитку конституціоналізму [7, с. 108]. Право на доступ до інформації останніми роками знаходить усе більше визнання в національному та міжнародному законодавстві. Багато держав прийняли закони про свободу інформації загалом і права на доступ до публічної інформації зокрема, показником чого $\epsilon$ глобальний індекс права на інформацію (right to information RTI). Право на інформацію, відповідно до Конвенції про захист прав людини та основоположних свобод, $\epsilon$ частиною більш широкого права на свободу вираження поглядів. Однак це не означає, що немає проблем із забезпеченням доступу до публічної інформації, розпорядниками якої є державні органи. Так, з одного боку, як зазначає спеціальний доповідач ООН щодо заохочення та захисту права на свободу думок та їх вираження, розвиток інформаційно-комунікаційних технологій розширює доступність, прозорість інформації про діяльність органів державної влади, а з іншого - $\epsilon$ тенденція обмеження урядами доступу до такого роду інформації шляхом поширення практики іiї надмірного засекречування, встановлення значних зборів та строків ії̈ надання тощо [27].

У сучасній літературі дослідники, розглядаючи генезис права на інформацію, зазначають, що «його зміст змінюється разом з розвитком цивілізації» $[2$, с. 415], що «кожне наступне покоління прав людини на інформацію надавало нових якостей, розширювало обсяг прав та свобод, але цей процес відбувався не стихійно, а завдяки постійній боротьбі прогресивних сил за свої права та свободи» $[15$, с. 4$]$.

На доктринальному рівні конституційне право на доступ до публічної інформації розглядають як «можливість особи, закріплену нормами конституції та деталізовану у законах з урахуванням міжнародно-правових стандартів, отримувати інформацію, що зафіксована на матеріальних носіях або відображена в електронному вигляді, від розпорядників, які володіють чи зобов'язані володіти нею, відповідно до чинного законодавства» [8, с. 17]. Важливою складовою частиною 
конституційного права на доступ до публічної інформації $\epsilon$ забезпечення ефективного механізму його захисту. Конституційне право на захист права доступу до публічної інформації можна розглядати у двох сенсах: 1) перше його значення, на думку О.М. Похіла, передбачає розуміння права доступу до публічної інформації у контексті забезпечення ним охоронних правовідносин превентивного характеру у процесі втілення саме захисних та правовідновлювальних функцій [16, с. 26]; 2) другий контекст означає наявність права на захист цих прав у будь-яких правовідносинах як забезпечення та одночасно їх гарантування. Щодо співвідношення понять «захист прав» та «правовий захист» необхідно зазначити, що вони перебувають між собою увідношенні субординації, тобто обсяг першого включається в обсяг другого. Правовий захист створює, зокрема, необхідну соціально-правову спрямованість поведінки людей, спрямовуючи їх волю та дії на реальне використання правових засобів захисту своїх прав, тоді як захист прав - це одна 3 юридичних форм державного управління, що забезпечує реальний правовий захист людини. Їх спільною рисою $є$ наявність юридичних механізмів, які перебувають у розпорядженні як держави, так і людини [1].

Заслуговує на увагу аналіз закономірностей формування та розвитку національного та міжнародного законодавства щодо доступу до публічної інформації, виокремлення поколінь національних законів, що регулюють цю сферу відносин та виявлення чинників, що впливають на його постійну трансформацію.

\section{1. Концептуальні засади права доступу до публічної інформації}

Розробка поняття «права людини» має давню історію, при цьому кожна історична епоха породжувала свою методологію концепції прав і свобод людини. Класична концепція прав і свобод людини походить із західної філософської доктрини XVII-XVIII ст. Першою ідеологічною передумовою виникнення вчення про права людини вважається поява гуманістичних підходів, заснованих на співвідношенні людини з навколишнім світом. У різні історичні періоди ідеї, які називають правами людини, набували різного звучання - чи то релігійного, чи то морально-етичного, чи то раціонально-обгрунтованого залежно від того, яка парадигма мислення була домінуючою у той час. Права людини тісно пов'язані з історичними уявленнями про свободу та справедливість як соціальні явища. Зокрема, ідеологічною основою 
виникнення та розвитку ідей про свободу інформації та законів, що закріплюють право на доступ до публічної інформації зокрема, $\epsilon$ ідеї просвітництва, які сформували концепції «природного права», «суспільного договору», «поділу та рівноваги гілок влади» «опору тиранії», а також захисту приватної власності, громадянських та особистих свобод. У XVIII столітті вони поширилися не лише на європейські країни, але й на американський континент і набули статусу міжнародної культури [9, с. 7]. Дослідники вказують на спадкоємність ідей європейського розвитку, що знайшло безпосереднє відображення у поглядах і судженнях філософів, учених, письменників, політичних і громадських діячів того часу [10, с. 7].

Після революції в Англії просвітницькі ідеї були сприйняті насамперед у Франції, де в Декларації прав людини і громадянина 1793 року був закріплений принцип свободи слова та прозорість влади, а також у Німеччині та Голландії. У Швеції філософські концепції просвітництва були розвинені менше, ніж в Англії та Франції, але саме у цій країні в 1766 році вперше був прийнятий законодавчий акт, який закріпив право на інформацію і принцип гласності для офіційних документів. У преамбулі цього документа наголошується на «великих перевагах, які народ отримує від законної свободи письма та друку, і що це не тільки сприятиме розвитку й поширенню наук i корисних ремесел, а й дасть можливості кожному з вірнопідданих отримувати більш глибокі знання та розуміння щодо мудрості налагодженої системи державного управління; і ця свобода також має розглядатися як один із найкращих засобів поліпшення моралі та заохочення до законослухняності та поваги до законів, тоді як зловживання i незаконні дії викриваються перед народом засобами друку» [12].

Дослідники наголошують на тому, що на законодавчому рівні закріпленню свободи інформації сприяли особливості становлення і розвитку демократичної системи цієї країни та парламентських процедур [13]. У XVIII столітті, який називають «золотим періодом» у розвитку шведського парламентаризму, в країні склалася своєрідна політична система, яка дозволила на практиці, а не на рівні теоретико-філософських дискусій реалізувати багато ідей епохи Просвітництва, зокрема щодо відкритості публічної інформації. У період 1718-1772 років державна влада у Швеції реалізовувалася: Сеймом як законодавчим органом, до складу якого входили представники чотирьох станів - дворянства, духовенства, бюргерів та селянства; 
підзвітною Сейму Радою Королівства як органу виконавчої влади; королем, влада якого була обмежена. За такого механізму реалізації державної влади можливість впливати на зміни у суспільстві, не вдаючись до насильства, була найбільш імовірною. При цьому забезпечення права доступу до інформації про стан справ у державі, а також гарантування свободи висловлення думки було найважливішою умовою впливу громадян на державну владу.

Вирішальний внесок у створення першого у світі закону про право на публічну інформацію внесли вчений і філософ Петер Форсколь (1732-1763) та просвітитель, мислитель та політик Андерс Хіденіус (1729-1803). Зокрема, Петер Форсколь у своїй дисертації «Громадянська свобода» писав, що свобода повинна підтримуватися через свободу, тобто свобода правління через свободу слова. Свобода слова гарантує розквіт наук, нагляд за державними посадовими особами та, зрештою, забезпечує стабільність уряду. Громадяни повинні мати можливість отримувати відповідну інформацію та використовувати їі для підвищення загального добробуту. Ідеї Форсколя стали передумовою прийняття у Швеції Закону про свободу друку, безпосередню участь у розробці якого брав Андерс Хіденіус, що відстоював концепцію щодо неподільності свободи [29, с. 21, 29-30].

Необхідно зазначити, що у XVIII столітті свобода друку була не тільки у Швеції, але й в інших країнах, наприклад в Англії дозволялося друкувати звіти про дебати в парламенті, проте це не було закріплено на законодавчому рівні. Багато дослідників шведського закону про свободу друку 1766 року бачать його головну мету у забезпеченні публічного доступу до офіційних документів і обгрунтовують це тим, що сім з п'ятнадцяти абзаців цього нормативно-правового акта були присвячені регулюванню ступеня цього публічного доступу. Так, було надано доступ до документів, що розглядалися у судах, органах законодавчої та виконавчої влади. Як правило, інформація щодо переговорів 3 іноземними державами також повинна бути відкритою для громадського контролю за винятком такої, що визнавалася державною таємницею, а також робочі документи, що перебували на стадії обговорення [32].

Хоча свобода слова і право на офіційну інформацію у 17721809 роках у Швеції були призупинені, принцип гласності став одним $з$ найважливіших чинників формування традиції побудови 
державного апарату у країнах Північної Європи. Новий закон Швеції про свободу друку був прийнятий у 1810 році, переглянутий у 1812 році та 3 поправками проіснував до 1949 року, після чого його змінив новий закон «Про свободу преси», в якому глава II має назву «Про гласність офіційних документів» [26]. Таким чином, понад двісті п'ятдесят років право на доступ до публічної інформації є невід'ємною частиною державного управління в Швеції та впливає на формування культури раціональної бюрократії з низьким ступенем корупції та високим ступенем суспільної довіри. У 1951 році законодавче закріплення права доступу до публічної інформації було реалізоване в іншій скандинавській країні, яку зі Швецією об'єднує історичне минуле, - Фінляндії.

Перш ніж розкрити механізм нормативного та інституційного забезпечення права на доступ до публічної інформації, необхідно з'ясувати, що $є$ публічною інформацією. Це важливо зробити, оскільки право доступу поширюється саме на публічну, а не приватну інформацію.

Загалом можна сказати, що публічна інформація - це вся інформація, що доступна громадськості. Висловлюється думка, що концепція публічної інформації може бути побудована на iї широкому та вузькому тлумаченні. Поняття публічної уширокому сенсі означає сукупність даних, отриманих або знайдених у будь-якому державному органі, незалежно від того, підготовлені вони чи отримані під час виконання своїх функцій. Це продукт суспільної діяльності різних органів держави. Згідно з вузьким підходом публічна інформація - це все, що виробляється під час виконання публічних функцій і відповідно до певної правової системи та вимог демократичного принципу має бути доступним для всієї спільноти, окремих осіб чи засобів масової інформації, за виключенням встановлених винятків, закріплених на конституційному та законодавчому рівні. Більшість дослідників відстоюють широкий підхід до розуміння публічної інформації, оскільки необгрунтованість такого роду інформації суттєво вплине на зміст права на доступ до публічної інформації та його реалізацію [31]. Також необхідно розрізнювати поняття публічної та адміністративної документації.

Право доступу до публічної інформації є ознакою ефективної конституційної демократії. Це право $\epsilon$ складником більш широкого права на свободу вираження поглядів, визнаного 
в основних документах Організації Об'єднаних Націй та регіональних систем захисту прав людини. Право на доступ до інформації отримало визнання як окреме право, гарантоване конституціями та іншими законами, яке покладає на державу обов'язок сприяти доступу всіх до інформації, якою володіють державні органи у будь-якій доступній формі або системах пошуку.

Серед публічної інформації на особливу увагу заслуговує публічна правова інформація. Дослідники цього питання наголошують, що Кожна особа має право доступу до такого виду публічної інформації, що покладає юридичний та моральний обов'язок на кожний уряд та кожну міжурядову організацію із судовими та законодавчими функціями щодо забезпечення належного та вільного доступу до їі законів. Крім того, послідовники такого підходу до тлумачення публічної правової інформації виступають за всезагальне визнання права публічного доступу до правової інформації як права людини та пропонують прийняти Конвенцію ООН про право публічного доступу до правової інформації. Прийняття такого документа, на думку німецького дослідника Л. Міті, значно покращить глобальний доступ до офіційної правової інформації, що сприятиме широкому знанню законодавства. Це також сприятиме національним та транснаціональним юридичним дослідженням, виправлятиме несправедливість щодо настання відповідальності за недоступними законами згідно з доктриною «незнання закону не позбавляє відповідальності» та сприятиме поширенню доктрини «незнання недоступного законодавства $€$ виправданням» [30].

Зростання значення права на публічну інформацію зумовлене декількома причинами. Доступ громадян до інформації про демократичне управління посилює громадський контроль уряду, що, ймовірно, зловживатиме публічною владою, якщо такого доступу не буде. Крім того, якість демократичних процесів посилюється за рахунок участі громадськості у прийнятті рішень належним чином поінформованими громадянами. Отже, оскільки демократія існує для захисту суспільних інтересів, гарантування права на інформацію публічного характеру посилює довіру громадськості до уряду та посилює відповідальність. Здатність громадян користуватися соціально-економічними правами посилюється завдяки можливості використовувати наявну інформацію, щоб змусити уряд виконувати свої зобов'язання. Крім того, доступ до публічної інформації $є$ життєво важливим 
інструментом боротьби з корупцією, роблячи діяльність уряду більш прозорою та ускладнюючи приховування незаконних дій.

\section{2. Генезис законодавчого врегулювання права на доступ до публічної інформації}

Може бути представлений у вигляді формування поколінь національних законів, що регламентують цю сферу суспільних відносин.

До першого покоління національних законів про доступ до публічної інформації належать перші законодавчі акти, прийняті у XVIII столітті: у Швеції у 1766 році; Франції - Декларація прав людини і громадянина 1789 року та закон 1794 року, який проголосив, що доступ до архівів більше не $\epsilon$ привілеєм, що надається сувереном вибраним посадовим особам, а $\epsilon$ громадянським правом, наданим усім. До законодавчих актів першого покоління також належать Декларація прав Вірджинії 1776 року, укладена Томасом Джефферсоном для вступних параграфів Декларації незалежності, яка стала основою Білля про права, а також Массачусетської декларації прав і Конституції 1780 року. Так, ст. 5 Массачусетської декларації прав і Конституції встановлювала, що оскільки «вся влада спочатку належить народу і походить від нього, то судді та представники законодавчої та виконавчої влади завжди підзвітні йому»; ст. 18 закріплювала право громадян здійснювати контроль за представниками законодавчої, судової та виконавчої влади у формуванні та виконанні законів, необхідних для належного управління співтовариством; ст. 19 передбачала право запитувати у законодавчого органу інформацію шляхом звернень і петицій [25]. Конституція США 1787 року також містила положення про «способи інформування громадян про діяльність влади шляхом публікації журналів про засідання парламенту США та звітів про надходження і витрачання усіх державних коштів» [4, с. 12].

До другого покоління законодавчих актів, які передбачають відкритість інформації про діяльність державних органів, належать конституції європейських держав, прийняті в XIX столітті: Норвегії (1814 рік), Бельгії (1831 рік), Нідерландів (1848 рік), Пруссії (1850 рік), Португалії (1826 рік), Швейцарії (1848 рік), які «забороняли цензуру, проголошували свободу слова та друку, публічність засідань парламентів (таємні засідання були винятком), а також передбачали опублікування 
парламентських дебатів у пресі. При цьому слід зазначити, що у цих конституційних актах не закріплювали права вимагати звіту від службових осіб та права стежити за використанням податків» [4, с. 13].

До третього покоління законодавчих актів, які передбачають відкритість інформації про діяльність державних органів, належать закони, прийняті після Другої світової війни у Фінляндії (1951 рік), США (1966 і 1974 роки), Данії і Норвегії (1970 рік), Франції та Нідерландах (1978 рік), Австралії та Новій Зеландії (1982 рік), Канаді (1983 рік). Ці закони приймалися здебільшого як частина адміністративних реформ у цих державах, їхньою метою було забезпечення більшої прозорості в діяльності урядів та участі громадян у прийнятті рішень.

Четверте покоління законодавства про відкритість публічної інформації було сформоване під впливом розпаду СРСР i соціалістичної системи в Європі, що вплинуло на прийняття державами пострадянського i постсоціалістичного простору нормативно-правових актів, які закріпили право на інформацію як фундаментальне права та елемент демократії. До конституцій цих держав були включені положення, що передбачають свободу інформації, у тому числі доступ до публічних документів. У законодавстві держав-членів Європейського Союзу доступ до інформації має статус загальної конституційної традиції [24]. Наприклад, у Конституції Франції право на доступ до адміністративних документів є основною гарантією, що надається для здійснення громадянських свобод.

П’яте покоління законодавчих актів, які передбачають відкритість інформації про діяльність державних органів, пов'язане з прийняттям спеціальних законів про доступ до публічної інформації. В Україні право на доступ до публічної інформації врегульований як на конституційному рівні, так і шляхом прийняття у 2011 році спеціального законодавчого акта - Закону «Про доступ до публічної інформації». Зокрема, ст. 34 Конституції України відносить право доступу до інформації до конституційних прав, зміст якого передбачає «право кожного на свободу думки і слова, на вільне вираження своїх поглядів і переконань; право вільно збирати, зберігати, використовувати і поширювати інформацію усно, письмово або в інший спосіб на свій вибір». Метою Закону 2011 року «Про доступ до публічної інформації» визначено «забезпечення прозорості та відкритості 
суб'єктів владних повноважень і створення механізмів реалізації права кожного на доступ до публічної інформації» [18].

Практика прийняття спеціального законодавства щодо врегулювання права доступу до публічної інформації у деяких європейських країнах, зокрема у Німеччині та Великобританії, певним чином відрізнялася від загальноєвропейських тенденцій розробки таких нормативно-правових актів, оскільки «нормативне регулювання доступу до такого роду інформації у цих двох країнах відбувалося в напрямі «знизу дороги»: у Великобританії - за рахунок стандартизації практики доступу, у Німеччині - за рахунок ухвалення земельних законів» [3, с. 10-11]. У Великобританії після тривалих дискусій такий законодавчий акт був прийнятий у 2000 році, а набув чинності лише у 2006 році, хоча практика кодифікації таких норм була розпочата у 1994 році, коли набув чинності Практичний кодекс із доступу до урядової інформації, який англійський парламент у 1997 році ухвалив як мінімальний стандарт відкритості. У Німеччині такий федеральний спеціальний інформаційний закон прийняли у 2005 році, хоча на рівні суб'єктів федерації, зокрема Берліну, Бранденбургу, Шлезвіг-Гольштайну у 1999-2000 роках.

У Польщі доступ до публічної інформації регулюється не лише законом «Про доступ до публічної інформації», але ще низкою законодавчих актів, серед яких - «Про Національний реєстр судів», «Про повторне використання інформації державного сектору». Зокрема, доступ до фінансової звітності компанії регулюється законом «Про Національний реєстр судів», а не «Про доступ до публічної інформації». Серед нормативних актів у цій сфері велике значення має закон «Про повторне використання інформації державного сектору». Повторне використання інформації державного сектору пов'язане з економічною та ринковою метою, а публічна інформація - це насамперед політичне право здійснювати контроль громадян над суспільним життям, тому сфери їх регулювання різняться, а способи розкриття публічної інформації та розкриття інформації державного сектору відносно подібні, але не ідентичні. Особливістю поводження з інформацією державного сектору $є$ те, що для повторного використання такої інформації може знадобитися згода того, хто ії надає, щодо публічної інформації така згода не потрібна.

У Греції доступ до публічної інформації регламентується ст. 5 Адміністративного процесуального кодексу та законом «Про 
доступ до інформації державного сектору», перша редакція якого набула чинності у 2006 році, а у 2020 набула чинності значно модернізована його версія. Необхідно зазначити, що Греція перша європейська країна, яка на конституційному рівні у 2001 році визнала право на доступ до сучасних технологій та участь у інформаційному суспільстві. Зокрема, в Основний закон включено ст. 5А, відповідно до якої «всі особи мають право на інформацію, зазначену у законодавстві. Обмеження цього права можуть бути встановлені лише законодавством, якщо вони необхідні та обгрунтовані 3 міркувань громадської безпеки, боротьби зі злочинністю або захисту прав третіх осіб». Другий абзац передбачає, що «всі особи мають право брати участь в інформаційному суспільстві. Сприяння доступу до даних, що передаються в електронному вигляді, а також їх виготовлення, обмін та розповсюдження, $є$ обов'язком держави. Більше того, зазначається, що права, визначені ст. 5А, випливають із права вільно визначати свою особистість [20]. Досвід Греції $\epsilon$ прикладом того, як на конституційному рівні може бути підкреслено важливість сучасних технологій у реалізації прав людини. Необхідно також звернути увагу на важливу норму, що міститься у Конституції Греції і якої немає у Конституції України, яка передбачає короткий термін прийняття парламентом закону, який захищає інформаційні права і свободи людини від нових загроз. Зокрема, у п. 4 ст. 76 Основного закону цієї країни передбачено, що «законопроєкти, які характеризуються вкрай терміновими, виносяться на голосування після обмеженого обговорення. Регламентом парламенту тривалість виступів та час обговорення можуть бути обмежені». Таким чином, як зазначає К.С. Полетило, «у разі появи нової інформаційної загрози суди Греції в змозі захистити права і свободи людини, адже вони можуть спиратись на необхідні закони» $[14$, с. 94].

у разі розкриття публічної інформації на вимогу громадськості поширеним $\epsilon$ конфлікт між правом кожної людини на публічну інформацію та вимогами національної безпеки щодо нерозкриття інформації певної категорії, при цьому межі такого роду інформації доволі часто безпідставно розширюються. Загалом перед національними законодавчими органами у разі формулювання законодавчих приписів, що гарантують право доступу до публічної інформації, постає багато питань, на що звертає увагу Тобі Мендель, зокрема: як спланувати систему 
виключень таким чином, щоб зберегти баланс між правом знати та необхідністю забезпечувати секретність для захисту певних ключових державних і приватних інтересів; яким має бути зобов'язання публікувати та поширювати інформацію; як може закон забезпечити виконання цього зобов'язання відповідно до розвитку технологій, які суттєво зменшують вартість публікації; які процедури запиту інформації можуть забезпечити баланс між необхідністю мати своєчасний, недорогий доступ до неї i проблемами тиску, а також обмеженості ресурсів, 3 якими стикаються державні службовці; яке право апеляції повинні мати люди, коли їм відмовляють у наданні інформації; які позитивні заходи необхідно вжити для зміни культури секретності, характерної для державного управління в багатьох країнах; як інформувати громадськість про їхні права? [11].

Визнаючи законний інтерес держави у відмові від розголошення певної інформації, у тому числі з міркувань національної безпеки, важливим $\epsilon$ досягнення балансу між розкриттям та відмовою розкривати інформацію у демократичному суспільстві, оскільки це має ключове значення і визначає його безпеку, прогрес і розвиток та процвітання, а також забезпечує найповніше користування правами людини та основними свободами. Незалежно від того, що відбувається під час конфлікту між зусиллями органів державної влади щодо збереження конфіденційності інформації через необхідність захисту національної безпеки та правом кожної особи на публічну інформацію, якою володіють органи державної влади, об'єктивний аналіз новітньої історії показує, що на практиці законні інтереси національної безпеки найкраще захищені тоді, коли громадськість добре поінформована про державну діяльність, у тому числі у сфері національної безпеки.

Цікавим $\epsilon$ досвід неєвропейських країн щодо прийняття законодавчих актів, які гарантують право на доступ до публічної інформації. Особливістю деяких з таких законів $\epsilon$ наявність у них положення про пріоритет суспільних інтересів у разі розкриття інформації. Закон Сьєрра-Леоне про право на доступ до інформації 2013 року гарантує це право кожній людині, але допускає нерозголошення інформації, яка «могла б завдати серйозної шкоди національній безпеці». Одночасно з цим розділ 12 закону передбачає перевірку пріоритету суспільного інтересу. Порівняно з Нігерією Закон Уганди про доступ до інформації 
2005 року, який реалізує конституційне право кожного громадянина на інформацію, у ст. 5 закріплює дещо вищий поріг нерозголошення, коли розкриття інформації може завдати шкоди державній безпеці. Закон Анголи про доступ до документів, що перебувають у веденні державної влади, 2002 року у ст. 32 наділяє главу державного органу правом приховувати інформацію, пов'язану з національною безпекою або обороною, після підтвердження того, що її розголошення, напевно, завдасть серйозної шкоди національній безпеці. Закон Руанди про доступ до інформації 2013 року передбачає широкі права на інформацію, про «факти, призначені для публікації, що містяться у виступах, звітах, листах, проспектах, журналах. При цьому засекречена інформація не підлягає опублікуванню, якщо вона може дестабілізувати національну безпеку». Закон Південного Судану про право на інформацію 2013 року захищає і гарантує право кожного громадянина на отримання інформації, відомостей, фактів або документів, що становлять суспільний інтерес, але дозволяє не розголошувати таку інформацію, яка може поставити під загрозу національну оборону і безпеку. У деяких африканських країнах $€$ закони, які не враховують суспільні інтереси. Так, Закон Буркіна-Фасо про доступ до публічної інформації та адміністративних документів 2014 року виключає засекречені документи і дані, розкриття яких може завдати серйозної шкоди національній обороні і державній безпеці. Закон Того про свободу інформації від 2016 року гарантує право громадян на публічну інформацію та документацію (ст. 1), за винятком інформації, пов'язаної з безпекою і національною обороною (ст. 2) [35].

Досвід країн Азіатсько-Тихоокеанського регіону щодо гарантування права на доступ до публічної інформації демонструє різні підходи цих країн до врегулювання цього питання, що зумовлене насамперед різним рівнем сприйняття демократичних цінностей у цих суспільствах. Так, в Австралії та Новій Зеландії закони про доступ до інформації взагалі були прийняті ще у 1982 році, при тому що значна кількість країн цього регіону почали приймати такі закони лише недавно. Зокрема, в Індії - у 2005 році, Монголії - у 2011 році, Бангладеш у 2009 році, Індонезії - у 2010 році, Шрі-Ланка - у 2016 році. Зокрема, останній із названих законів не тільки дозволяє громадянам ефективніше брати участь у прийнятті рішень, але 
також дозволяє громадянам подавати запити щодо будь-якої інформації, якою володіють державні установи, і вимагає активного розкриття інформації цими установами.

У багатьох країнах світу досі відсутні закони, що визначають право на публічну інформацію як важливий компонент для розвитку та підтримки суспільної довіри до уряду, таких як Алжир, Камерун, Чад, Гана, Лесото, Лівія, Сомалі, Замбія, Сейшельські Острови, Демократична Республіка Конго, Північна Корея.

Північна Корея, мабуть, чи не найзакритіша країна світу із тоталітарним режимом правління. Ця країна має найнижчі показники у міжнародних рейтингах, які дають можливість оцінити відкритість суспільства, рівень забезпечення прав людини, у тому числі інформаційних: Індекс демократії (Democracy Index), що складається "Economist Intelligence Unit" за рівнем розвитку в них демократії; Всесвітній індекс свободи преси, який складає міжнародна організація «Репортери без кордонів» (Reporters Sans Frontières). У звітах цих організацій констатується відсутність доступу до зовнішніх джерел інформації у цій країні. Екстремальні заходи, які застосовує державна влада Північної Кореї, щоб запобігти доступу громадян до зовнішньої інформації, були задокументовані слідчою комісією ООН щодо прав людини Північної Кореї. В одному із розділів цього документа зосереджено увагу на порушеннях свободи думки та вираження поглядів i містять детальну інформацію про методи, що використовуються для обмеження доступу до інформації та блокування сторонніх думок та поглядів. У цій країні існує тотальний контроль над усіма засобами масової інформації. Порушники встановлених недемократичних положень притягуються до суворої відповідальності. Наприклад, наприкінці 2017 року суд Північної Кореї засудив двох південнокорейських журналістів та керівників двох провідних південнокорейських газет, у яких їхня робота була опублікована, до смертної кари (заочно) за образи гідності Північної Кореї і без можливості оскарження. Інтернет громадянам цієї країни просто недоступний [28]. Зрозуміло, що в таких умовах право на доступ до публічної інформації взагалі не може існувати.

Стрімкий розвиток інформаційних технологій дозволяє значно полегшити громадянам доступ до публічної інформації, яка їм потрібна або яка призначена для них. У зв'язку із цим науковою спільнотою обговорюються питання: чи $\epsilon$ доступ до Інтернету автономним правом чи лише передумовою користування іншими 
правами, зокрема свободою вираження поглядів та доступу до публічної інформації; чи несе він нормативні наслідки? [33]. Першою країною, яка визнала право на доступ до Інтернету, $\epsilon$ Естонія. Кожна особа має право відповідно до розділу 33 закону «Про доступ до публічної інформації» на доступ до публічної інформації через підключення до Інтернету, доступне в публічних бібліотеках. У законодавчому акті про публічні бібліотеки у § 15 сек. 21 зазначається, що кожна людина повинна мати можливість користуватися комп'ютером, щоб отримати доступ до інформації, доступної через публічні телекомунікаційні мережі [5].

Випробуванням на стійкість національних правових режимів щодо гарантування доступності інформації публічного характеру стала пандемія COVID-19, яка спричинила накладання певних обмежень. За інформацією, що міститься у щорічному звіті міжнародної неурядової правозахисної організації Amnesty International, з перших днів поширення COVID-19 влада кількох країн регіону, в якій вперше був зафіксована ця хвороба, намагалася приховати інформацію про це і карала тих, хто критикував дії уряду. Китайська влада прагнула контролювати інформацію про COVID-19 як онлайн, так і офлайн. Ключові слова, пов'язані з вірусом, були заблоковані, а онлайн-протести з вимогою права отримувати та поширювати інформацію про COVID-19 були видалені. Кілька інших країн регіону ввели аналогічні обмеження щодо того, що можна чи не можна говорити про COVID-19, часто під приводом боротьби 3 поширенням недостовірної інформації. Наприклад, у Непалі уряд вніс кілька нових законопроєктів, які загрожували праву на свободу вираження поглядів у режимі онлайн та офлайн. У Сінгапурі, навіть коли його оскаржували у суді, влада використовувала Закон про захист від неправди та маніпуляцій в Інтернеті, щоб здійснювати тиск на незалежні ЗМІ. В екстремальних для всього світу умовах, що спричинила пандемія, право на свободу вираження поглядів, що включає право отримувати та поширювати інформацію, $\epsilon$ особливо важливим, доступ до достовірної, об’єктивної та обгрунтованої інформації про пандемію COVID-19 рятує життя [23].

Крім трагічних наслідків для здоров'я в усьому світі, пандемія COVID-19 актуалізувала проблеми доступу до Інтернету, а також полеміку щодо визнання доступу до Інтернету правом людини, наданим урядом, оскільки без нього інші права людини, включаючи право на працю та право на базову освіту, не можуть бути належним чином реалізовані. У 2016 році Генеральна 
Асамблея $\mathrm{OOH}$ прийняла необов'язкову резолюцію, яка проголосила доступ до Інтернету правом людини. Положення цього документа випливають зі ст. 19 Загальної декларації прав людини і розглядається як «м'яке право», на відміну від «жорсткого права», що означає, що національні держави не піддаються значним санкціям за їх недотримання.

На підставі аналізу законодавства, що регулює питання доступу до публічної інформації, видається можливим виокремити підходи, відповідно до яких визначається місце права доступу до публічної інформації у системі прав людини: 1) право на доступ до публічної інформації виникає зі свободи преси (Швеція, інші скандинавські держави, США); 2) право на доступ до публічної інформації базується на свободі вираження думки та прозорості діяльності державних органів. Другий підхід $\epsilon$ більш поширеним.

\section{3. Міжнародно-правові стандарти захисту права на публічну інформацію}

Справедливою $є$ думка про те, що міжнародно-правовий захист права людини на інформацію, якою володіють державні органи, є сукупність норм і принципів міжнародного права, які становлять специфічну галузь цієї системи права і регулюють дії його суб'єктів з приводу захисту, охорони та забезпечення цих прав, а механізм міжнародного захисту прав людини на публічну інформацію слід розглядати як систему міжнародних органів та організацій, які діють 3 метою здійснення міжнародних стандартів інформаційних прав та свобод людини або їхнього відновлення в разі порушення [2, с. 141]. Залежно від рівня правової регламентації можна виділити два основні інституційні механізми його забезпечення: 1) міжнародний (у тому числі міжнародний регіональний); 2) національний.

Першим міжнародним документом універсального характеру, що стосується права доступу до інформації органів державної влади, є Резолюція № 59/I, прийнята 14 грудня 1946 року на першій сесії ОOH, у якій проголошувалося, що право на інформацію $є$ основним правом людини та мірою всіх інших свобод. Загальна декларація прав людини 1948 року та Міжнародний пакт про громадянські та політичні права 1966 року у ст. 19 визнали, що кожна людина має право на свободу думок та ïx вільне вираження, що це право включає усебе свободу мати 
незалежну думку, шукати, одержувати та поширювати інформацію та думки будь-яким способом, незалежно від кордонів. Хоча ст. 19 Міжнародного пакту про громадянські та політичні права спочатку не передбачала права на інформацію, але починаючи 3 1995 року органи ООН змогли використати свободу вираження поглядів, що охоплює право на інформацію. Наприклад, Спеціальний доповідач $\mathrm{OOH}$ із питань свободи вираження поглядів у звіті 1995 року Комісії ООН з прав людини заявив, що свобода буде позбавлена ефективності, якщо люди не матимуть доступу до інформації, та продовжував підкреслювати фундаментальний характер права на інформацію. У 1997 році Спеціальний доповідач $\mathrm{OOH}$ визнав, що право «шукати, отримувати та поширювати інформацію», закріплене уст.19 Загальної декларації прав людини, покладає на держави позитивне зобов'язання забезпечити доступ до інформації, особливо стосовно інформації, якою володіють уряди в усіх типах систем зберігання та пошуку». У 1999 році Спеціальний доповідач ООН та два інші спеціальні механізми правозахисту у Спільній декларації про свободу інформації зазначили, що свобода вираження поглядів передбачає право громадськості відкривати доступ до інформації та знати, що уряди роблять від їхнього імені, без чого правда занепадала б, а участь людей в урядуванні проявлялася лише фрагментарно. У наступних доповідях $\mathrm{OOH}$ з цього питання зазначалося, що право на доступ до інформації, що належить державним органам, $\epsilon$ основним правом людини, яке повинно набути чинності на національному рівні шляхом усебічного законодавчого закріплення, що грунтується на Принципах законодавства про свободу інформації, які містять мінімальні стандарти законодавства про право на інформацію. «Максимальне розкриття» підтверджує зобов'язання оприлюднювати всю офіційну інформацію, за винятком чітких і вузьких винятків. «Обов'язок публікувати» встановлює обов'язок активно публікувати інформацію, що становить суспільний інтерес. Принцип «просування відкритого уряду» визнає зобов'язання держав щодо вирішення державної таємниці. «Обмежений обсяг винятків» забороняє винятки, які захищають уряд від збентеження або виявлення правопорушень, піддаючи нерозголошення перекриттю суспільних інтересів. Нарешті, право на інформацію або закон про свободу інформації мають першість над законами про таємницю. 
Регіональний рівень регулювання права на доступ до публічної інформації представлений насамперед стандартами, розробленими Радою Європи та Європейським Союзом. У Європейській конвенції про права людини 1950 року у ст. 10 закріплено право кожної людини на свободу вираження, що включає свободу дотримуватися своїх поглядів, а також отримувати та передавати інформацію та ідеї без втручання. Важливим елементом, що регулює питання доступу до публічної інформації в межах Ради Європи, є документи м'якого права у формі рекомендацій, адресованих державам-членам, без статусу обов'язкового законодавства, вони лише вказують на загальновизнані стандарти поведінки. Прикладом наведемо Рекомендації R (81) 19 Комітету міністрів Ради Європи від 25 листопада 1981 року щодо доступу до інформації, що зберігається державними органами. Цей документ містить принцип необмеженого доступу до інформації, згідно з яким кожна особа, що перебуває під юрисдикцією держави-члена Ради Європи, має право отримувати дані, що зберігаються органами законодавчої, виконавчої та судової влади. В інших рекомендаціях щодо цього питання передбачалося, що доступ до інформації повинен бути гарантований на засадах рівності, відсутність законного інтересу заявника не $\epsilon$ підставою для відмови у наданні інформації. Також було передбачено, що обмеження доступу до інформації має випливати з принципів, необхідних у демократичній державі для захисту суспільних інтересів, приватного життя інших осіб та інших законних інтересів. Також було уточнено, що відмова у наданні інформації повинна бути обгрунтованою та передбачати можливість оскарження такого рішення. На основі рекомендацій Комітету міністрів Ради Європи щодо офіційних документів експертна група розробила Конвенцію «Про доступ до офіційних документів», що $\epsilon$ першим юридично обов'язковим міжнародним документом про доступ до документів такого роду, який набув чинності лише у 2020 році. Необхідно відзначити, що надала чинності цій конвенції саме ії ратифікація Україною у травні 2020 року, оскільки за умовами цього нормативно-правового акта його мали підписати не менше 17 країн. 3 цього приводу $\epsilon$ сенс зазначити, це дасть можливість повною мірою використовувати європейський правозахисний механізм щодо забезпечення прав на доступ до публічної інформації. 
Що стосується доступу громадян держав-членів Європейського Союзу до документів європейських установ, то це право містилося спочатку у додатку до Маастрихтського договору 1992 року і гарантувалося ст. 255, потім в Амстердамському договорі 1997 року, а також підтверджувалося Хартією основних прав ЄС 2000 року. Лісабонський договір 2007 року, який набув чинності в 2009 році, закріпив його у ст. 15 як основне право, відповідно до якого установи, служби та агенції Союзу функціонують з метою сприяння належному врядуванню та забезпеченню участі громадянського суспільства у цьому процесі. Кожна фізична або юридична особа, яка проживає або має юридичну адресу на території держави-члена, має право доступу до документів установ, органів, служб та агенцій Союзу, відтворених на будь-якому носієві, за умов дотримання принципів та умов, визначених Європейським Парламентом та Радою за допомогою регламентів згідно зі звичайною законодавчою процедурою» [6].

Головним судовим органом універсального рівня, створеним у рамках $\mathrm{OOH}, \epsilon$ Міжнародний суд $\mathrm{OOH}$, до завдань якого входить здійснення міжнародного правосуддя. Його склад і компетенція визначені Статутом ООН та Статутом Міжнародного Суду ОOH. До регіональних міжнародних судових органів щодо захисту права на доступ до публічної інформації належать: Європейський суд з прав людини, Міжамериканський суд з прав людини, Африканський суд з прав людини і народів.

Перше рішення Європейського суду 3 прав людини, яке стосується права на доступ до публічної інформації, було винесене ще у 1987 році у справі «Леандер проти Швеції» ("Leander v. Sweden"). У ньому було викладено правову позицію, яка стала стандартом у цій сфері: «право на свободу одержувати інформацію, в основному, забороняє Уряду встановлювати будьякій особі обмеження одержувати інформацію, яку інші особи бажають або можуть бажати повідомити їй. 3 урахуванням обставин нинішньої справи стаття 10 Конвенції про захист прав людини і основоположних свобод не дає приватній особі право на доступ до реєстру, який містить інформацію про її особистий стан, і не покладає на Уряд зобов'язання повідомляти цю інформацію приватній особі» [17]. Отже, Суд прямо зазначив, що Конвенція не покладає обов'язок на держави забезпечувати доступ до інформації, яка перебуває у їх володінні. 
У наступних рішеннях Європейський суд 3 прав людини, дотримуючись викладеного вище стандарту, розширює захист ст. 10 Конвенції про захист прав людини і основоположних свобод у напрямі формулювання правових позицій щодо захисту права на доступ до публічної інформації. Так, Європейський суд з прав людини у рішенні від 14 квітня 2009 року у справі «Угорська спілка громадянських свобод проти Угорщини» (“Társaság a Szabadságjogokért v. Hungary") заявив, що громадськість має право на інформацію суспільного значення. Справа стосувалася заяви угорської організації Társaság a Szabadságjogokért про доступ до заяви угорського депутата, в якій він вимагав перевірити конституційність кримінального закону про наркотики після внесення поправок. Як підкреслив Трибунал, створення перешкод для доступу неурядової організації до публічної інформації становить обмеження свободи слова та може негативно вплинути на якість та стан публічних дебатів. Особлива роль відводиться засобам масової інформації та неурядовим організаціям [21].

Європейський суд 3 прав людини вважає, що свобода вираження думок включає у себе право громадськості на адекватну інформацію, зокрема з питань, що становлять суспільний інтерес (справа «Маковей проти Румунії», 2015 рік). Важливим для формування відповідної практики Європейського суду з прав людини є рішення Великої палати від 8 листопада 2016 року в справі «Угорський Гельсінський комітет проти Угорщини» ("Magyar Helsinki Bizottság v. Hungary"). Заява до Великої палати виникла через відмову двох відділів поліції розкрити угорській правозахисній організації імена призначених державних захисників. До цього судові установи різних рівнів цієї країни відмовляли у задоволенні позову Угорського Гельсінського комітету під час розгляду цього питання у межах національної юрисдикції, посилаючись на те, що діяльність державного захисника $є$ приватною діяльністю, і відділи поліції не зобов'язані передавати свої персональні дані відповідно до Закону про дані. Європейський суд з цього приводу дійшов висновку, що хоча ст. 10 ЄКПЛ не надає особі загального права доступу до інформації, що належить державним органам, таке право може виникнути в окремих випадках. Також було сформулювано порогові критерії, щоб оцінити, чи відмова у доступі до інформації стосується ст. 10 ЄКПЛ на підставі того, що ця інформація $\epsilon$ інструментом для реалізації особою свого права на свободу вираження поглядів [22]. 
Регіональний рівень регламентації прав людини на доступ до публічної інформації представлений також документами, прийнятими такими міжнародними регіональними організаціями, як Організація Американських держав, Африканський Союз, Асоціація держав Південно-Східної Азії (ASEAN) та ін.

Американські стандарти захисту права на доступ до публічної інформації відображені у змісті статті 13 Американської конвенції 3 прав людини, статті IV Американської декларації прав та обов'язків людини та ст. 4 Міжамериканської демократичної хартії. На відміну від ст. 10 ЄКПЛ, ст. 13 Американської конвенції з прав людини визнає право кожної особи на пошук та доступ до будь-якого типу публічної інформації, а також відповідний обов'язок держави надавати її.

Крім Європейського суду 3 прав людини, наявні інші регіональні судові інституції, які сформували відповідну практику щодо захисту права на доступ до публічної інформації. Наприклад, юрисдикція Міжамериканського суду щодо права на свободу вираження, яке включає не лише право кожного висловлювати власні думки, але й право шукати та отримувати будь-яку інформацію, була поширена на захист таких прав лише у 2001 році, хоча до цього Суд звертався до тлумачення ст. 13 Американської конвенції з прав людини у двох консультативних висновках. Так, рішення Міжамериканського суд з прав людини у справі «Клод Рейєс та ін. проти Чилі» (2006 рік) стосується міжнародної відповідальності Чилійської держави за відмову надати інформацію про проєкт лісового господарства Марселю Клоду Рейєсу та відсутність адекватного та ефективного засобу правового захисту для оскарження рішення.

Міжамериканський суд, щоб використати потенціал ст. 13, надав додаткові роз'яснення щодо реалізації цього права у справі «Гомес Лунд проти Бразилії» (2010 рік). У цьому разі минуло двадцять п'ять років з моменту подання запиту, зробленого родичами жертв насильницького зникнення під час військових операцій проти партизанів у Бразилії, на доступ до інформації 3 цього питання. Суд засудив Бразилію за порушення свободи вираження поглядів, передбачене ст. 13 Американської конвенції, на тій підставі, що запити мають бути розглянуті протягом розумного строку [34].

Африканська система прав людини визнає право на доступ до публічної інформації, зокрема, за ст. 9 Африканської хартії прав 
людини i народів, «кожна особа має право отримувати інформацію; кожна особа має право висловлювати та поширювати свою думку в рамках закону». Реалізація цих положень не може бути обмежена $з$ міркувань національної безпеки, за винятком випадків, коли це очевидно виправдано законом і для законних цілей.

За даними Африканської комісії з прав людини та народів, ст. 9 означає, що свобода вираження поглядів $\epsilon$ основним правом, життєво важливим для особистого розвитку та участі громадян. Необхідно зазначити, що у рамках вузького тлумачення змісту цієї статті вона не гарантує право на одержання інформації, яку держава може не бажати оприлюднювати. 3 метою забезпечення широкого тлумачення ст. 9 Африканської хартії прав людини і народів Африканська комісія з прав людини та народів застосувала творчий інтерпретаційний підхід до розробки положень Хартії, які неповною мірою розкривають та закріплюють деякі права людини, заснований на взаємопов'язаності прав, позитивних зобов'язань. Як справедливо зауважила Африканська комісія усправі «Центр дій із соціальних та економічних прав та інші проти Нігерії», що колективні права, екологічні права, а також економічні та соціальні права $\epsilon$ важливими елементами прав людини в Африці. Африканська комісія буде застосовувати будьяке з різноманітних прав, що містяться в Африканській хартії прав людини і народів. Також наголошується, що у Хартії немає прав, які не можна було б зробити ефективними. Таким чином, Африканська комісія сприяла здійсненню явно не гарантованих прав, вирішивши, що права, які прямо не передбачені Хартією, можуть матися на увазі.

3 огляду на вузьку сферу застосування ст. 9 Африканської хартії прав людини і народів, Африканська комісія у 2002 році прийняла додаткову, хоча і таку, що не має обов'язкової сили, Декларацію принципів свободи вираження думок і доступу до інформації в Африці. Ця декларація «підтримує дух ст. 9» та закріпила положення, яке означає, що свобода вираження поглядів та інформації є фундаментальним і невід'ємним правом та важливим чинником демократичного розвитку, що державні органи зберігають інформацію не для себе і кожен має право на доступ до такої інформації за умовами та правилами, встановленими законом. Ця Декларація синхронізує ст. 9 Африканської хартії прав людини і народів 3 міжнародними стандартами і принципами права доступу 
до публічної інформації та встановлює зв'язок між цим правом і правом на свободу вираження поглядів. Декларація визнає, що свобода вираження думок включає право на інформацію, необхідну для прозорості, підзвітності та зміцнення демократії. У цьому документі підтверджує позитивний обов'язок держав гарантувати це право за умови дотримання чітко визначених правил, встановлених законом, включаючи інформацію. Декларація зберігає принцип активного розкриття інформації, вимагаючи від державних органів активно публікувати інформацію, що являє значний суспільний інтерес «навіть за відсутності запиту», захищає розкриття інформації, що становить суспільний інтерес. Важливим $\epsilon$ положення, за яким будь-яке порушення права на інформацію може бути оскаржене. Декларація формулює позитивне зобов'язання держав вносити поправки у свої закони про конфіденційність, щоб вони відповідали «принципам свободи інформації». Для виконання зобов'язання щодо забезпечення прозорості в управлінні Спеціальний доповідач Африканської комісії зі свободи вираження думки розробив Типовий закон про доступ до інформації в Африці, який спрямований на те, щоб допомогти національним законодавцям «перетворити» відкрите формулювання права доступу до інформації в конкретні законодавчі положення, що дозволяють створити ефективну національну систему доступу до публічної інформації. Також у ст. 1 Типового закону міститься всеосяжне визначення «інформації», що охоплює документальні, аудіовізуальні, матеріальні та нематеріальні матеріали, незалежно від того, чи з'явилася інформація до дати набуття законом чинності. Цей документ закріплює такі принципи поводження з інформацією, як максимальне розкриття і презумпція розкриття (ст. 2); активне розкриття інформації (ст. 7); закон про верховенство права на інформацію (ст. 4); обмежені винятки (частина III, розділи 24-39) [35].

Таким чином, аналіз судової практики Європейського суду з прав людини та Міжамериканського суду з прав людини показує, що, ймовірно, саме регіональні рамки забезпечують найбільший обсяг та найширші гарантії захисту права на доступ до публічної інформації як прояву свободу думки та вираження поглядів.

Необхідно мати на увазі, що міжнародний механізм захисту права на доступ до публічної інформації не може існувати незалежно від національних механізмів, він ефективно функціонує як додатковий стосовно національних механізмів його гарантування. Міжнародно-універсальне та міжнародно-регіональне 
регулювання і контроль за порушенням прав людини, у тому числі щодо доступу до публічної інформації, повинні насамперед бути спрямовані на підвищення ефективності внутрішньодержавних правопорядків. В Україні ще не створено ефективну систему реалізації права на доступ до публічної інформації. Так, за даними Уповноваженого Верховної Ради 3 прав людини, приблизно $11 \%$ скарг, які надходять до цієї правозахисної інституції, стосуються додержання права на доступ до публічної та суспільно важливої інформації, що зумовлює «необхідність покращення законодавчого регулювання у цій сфері та вироблення єдиної судової практики та підходів до вирішення спорів, які виникають між розпорядниками та відповідно запитувачами інформації» $[19$, c. 4].

Стрімкий розвиток інформаційних технологій дозволяє значно полегшити громадянам доступ до публічної інформації, яка їм потрібна або яка призначена для них, наприклад, у 2019 році у Спільній декларації ОБСЄ, Міжамериканської комісії з прав людини та Спеціального доповідача з питань свободи слова та доступу до інформації рекомендується визнати право на доступ до Інтернету правом людини та обов'язкову умову здійснення права на свободу вираження [36].

Більшість досліджень у всьому світі показують, що доступ до Інтернету зараз $\epsilon$ життєво важливим для доступу до роботи, освіти, для покращення прав працівників, а також для забезпечення свободи вираження поглядів та доступу до інформації.

\section{Висновки}

Прозорість у діяльності органів державної влади $\epsilon$ визначальною засадою для демократичної держави. Це - основна гарантія довіри громадян до держави та прийнятого закону, без якої неможливе гармонійне функціонування суспільства. Інформація про діяльність органів державної влади може мати значення як для окремої людини, так і для широкого кола громадськості. Реалізація цього права $\epsilon$ одним із основних інструментів контролю громадян за державною владою, тому так важливо забезпечити максимально широкий доступ до публічної інформації. Право на доступ до інформації, якою володіють органи державної влади, або право на публічну інформацію є основним, фундаментальним правом людини. Довгий час воно розглядалося як напрям модернізації системи адміністрування, а нині його 
покладено в основу стратегій, розроблених міжурядовими організаціями та національними урядами, спрямованих на протидію корупції, на захист навколишнього середовища тощо.

Пандемія COVID-19 підкреслила важливість інформації під час кризи. Право на доступ до публічної інформації в останні десятиліття знаходить усе більше визнання в національному та міжнародному законодавстві. Нині велика кількість держав прийняли спеціальні закони щодо врегулювання доступу до публічної інформації.

Розвиток права на доступ до публічної інформації може бути представлений у вигляді формування поколінь національних законів, що регламентують цю сферу суспільних відносин. Слід мати на увазі, що прийняття закону - це лише перший крок до забезпечення доступності інформації, якою володіють державні органи. Це право покладає на держави позитивне зобов'язання визнавати його та розробляти зручні для користувачів системи, що забезпечують практичний доступ до такої інформації як шляхом відповіді на запити щодо інформації, так і шляхом завчасного її розкриття.

\section{Список використаних джерел:}

1. Баранова С.Г. Конституционное право человека и гражданина на правовую защиту: дис.. ... канд. юрид. наук : 12.00.02. Екатеринбург, 2004. 190 с.

2. Войтович П.П. Інформаційні права людини: міжнародноправовий захист : монографія. Одеса : Гельветика, 2017. 220 с.

3. Електронне урядування та електронна демократія : навчальний посібник у 15 ч. Київ : ФОП Москаленко О.М., 2017. Частина 11: Доступ до публічної інформації / Ю.Б. Пігарєв, B.M. Дрешпак, I.C. Куспляк. 2017. 60 c. URL: https://onat.edu.ua/wpcontent/uploads/2018/05/Part_011_Feb_2018.pdf.

4. Закон України «Про доступ до публічної інформації»: науково-практичний коментар / за ред. Д. Котляра. Київ, 2012. 170 c. URL: https://www.president.gov.ua/storage/j-files-storage/ 00/01/28/7efd195590f891f51d636939b9dd0ca9_1432818344.pdf.

5. Закон Эстонской Республики о публичной информации : принят 15.11.2000 г. RT I 2000, 92, 597. URL: https://www.juristaitab.ee//sites/www.juristaitab.ee/files/elfinder/ ru-seadused/\%d0\%97\%d0\%90\%d0\%9a\%d0\%9e\%d0\%9d\%20\%d0\% 9e\%20\%d0\%9f\%d0\%a3\%d0\%91\%d0\%9b\%d0\%98\%d0\%a7\%d0\% 
9d\%d0\%9e\%d0\%99\%20\%d0\%98\%d0\%9d\%d0\%a4\%d0\%9e\%d0\% a0\%d0\%9c\%d0\%90\%d0\%a6\%d0\%98\%d0\%98\%2001.12.18.pdf.

6. Консолідовані версії Договору про Європейський Союз та Договору про функціонування Європейського Союзу (2010/C 8301). URL: https://zakon.rada.gov.ua/laws/show/994_b06\#Text.

7. Крусян А.Р. Генезис та основні тенденції розвитку сучасного конституціоналізму. Наукові праці Одеської національної юридичної академії : зб. наук. пр. Одеса, 2005. T. IV. С. 102-110.

8. Кушнір I.B. Конституційне право особи на доступ до публічної інформації та його забезпечення Уповноваженим Верховної Ради з прав людини : дис ... канд. юрид. наук : 12.00.02. Київ, 2018. 251 с.

9. Лабутина Т.Л., Ильин Д.В. Английское Просвещение: общественно-политическая и педагогическая мысль. СанктПетербург : Алетейя, 2018. 312 с.

10. Марченко М.Н. Эволюция европейских объединительных идей (XI-XIX вв.). Вестник Московского университета. Сер.11. Право. 2008. Вып. 3. С. 3-13.

11. Мендел Тоби. Свобода информации: сравнительноправовое исследование. ЮНЕСКО. Париж, 2008. URL: https://unesdoc.unesco.org/ark:/48223/pf0000158450_rus.

12. Милостивий Указ його Величності про свободу письма й друку (1766, Королівство Швеція) / переклад А. Чорноморченка. Центр демократії та верховенства права. 2016. URL: https://cedem.org.ua/library/13118/.

13. Новицкая И.Я. Первый государственный акт об отмене цензуры в Швеции, узаконенный 2 декабря 1766 года Его Королевского Величества Милостивым Постановлением относительно свободы выхода в свет рукописных и печатных изданий: исторические предпосылки и персоналии. Москва, 2013. 206 с.

14. Полетило К.С. Інформаційні права людини і свободи та їх судовий захист у конституційних нормах Греції. Правова інформатика. 2014. № 1. С. 88-95.

15. Політанський В.С. Право на інформацію як фундаментальне право людини: монографія. Харків: Право, 2017. 208 c.

16. Похил О.М. Поняття і зміст конституційного права на захист своїх прав. Юридична Україна. 2009. № 5. С. 25-29.

17. Правові позиції Європейського суду 3 прав людини усправах щодо доступу до публічної інформації / укладач Христина Буртник. 2020. 142 c. URL: https://rm.coe.int/echr-cases2020-web/1680a10d12. 
18. Про доступ до публічної інформації : Закон України від 13.01.2011 р. № 2939-VI. (у редакції від 24.10.2020). URL: https://zakon.rada.gov.ua/laws/show/2939-17\#Text.

19. Рекомендації Уповноваженого Верховної Ради України з прав людини 3 питань додержання конституційного права людини і громадянина на доступ до інформації / Т. Олексіюк, Л. Опришко, Х. Буртник, В. Барвіцький, О. Кабанов. Київ, 2020. 336 с. URL: https://rm.coe.int/recomendations-final-10-02-21/1680a165f7.

20. Constitutional Provisions for Access to Information. Access Info Europe. Defending and Promoting the Right of Access to Information in Europe. URL: https://www.access-info.org/2013-0715/constitutional-provisions-for-ati/.

21. Угорська спілка громадянських свобод проти Угорщини ("Társaság a Szabadságjogokért v. Hungary") : рішення Європейського суду 3 прав людини у справі №37374/05 від 14.04 .2009 р. URL: $\quad$ https://hudoc.echr.coe.int/eng\#\{\%22itemid\%22:[\%2200192171\%22]\}.

22. «Угорський Гельсінський комітет проти Угорщини» ("Magyar Helsinki Bizottság v. Hungary") : рішення Європейського суду 3 прав людини у справі № 18030/11 від 08.1.2016 p. URL: https://hudoc.echr.coe.int/eng\#\{\%22itemid\%22:[\%22001$167828 \% 22]\} /$

23. Back to Asia and the Pacific ASIA-PACIFIC 2020. Права человека в современном мире : доклад Amnesty International. 2020/2021. URL: https://www.amnesty.org/en/wp-content/uploads/2021/06/\%D1\% 80\%D1\%83\%D1\%81\%D1\%81\%D0\%BA\%D0\%B8\%D0\%B8\%CC\%86. pdf.

24. Bouhadana I. The right of Access to Public Information: An Analysis of International Conventions. Revue Internationale des Gouvernements Ouverts. 2015. T.2. URL: https://ojs.imodev.org/ index.php/RIGO/article/view/1/67.

25. Constitution of Massachusetts. 1780. URL: http://www.nhinet. org/ccs/docs/ma-1780.htm.

26. Jonason P. Le droit d'accès à l'information en droit suédois : une épopée de 250 ans. Revue Internationale des Gouvernements Ouverts. 2016. T. 2. URL: https://ojs.imodev.org/index.php/ RIDDN/article/view/137/175.

27. Kaye David. Challenges to Freedom of Information in the Digital Age. URL: https://www.swlaw.edu/sites/default/files/201804/JIMEL_V7\%2C_N2_-_Challenges_to_Freedom_of_Information_in_ the_Digital_Age.pdf. 
28. King Robert R. North Koreans Want External Information, But Kim Jong-Un Seeks to Limit Access. Center for Strategic International studies. 2019. 15 may. URL: https://www.csis.org/analysis/northkoreans-want-external-information-kim-jong-un-seeks-limit-access.

29. Manninen Juha. Anders Chydenius and the Origins of World's First Freedom of Information Act. The World's First Freedom of Information Act. Anders Chydenius' Legacy Today. Anders Chydenius Foundation. Kokkola: Art-Print Ltd, 2006. P. 18-53. URL: https://www.chydenius.net/tiedostot/worlds_first_foia.pdf.

30. Mitee L. The Right of Public Access to Legal Information: A Proposal for its Universal Recognition as a Human Right. German Law Journal. 2017. Vol.18, No.6. P.1429-1496. DOI: 10.1017/ S2071832200022392.

31. Muñoz Jorge Astudillo. Notes regarding transparency in the exercise of public functions and the right of accessto public information. Revista Facultad de Jurisprudencia. 2021. No. 9. P. 385-429.

32. Nordin J. The Swedish Freedom of Print Act of 1776 Background and Significance. URL: https://www.swlaw.edu/sites/ default/files/2018-04/Nordin\%20Pages\%20from\%207.2\%20FULL\% 20v7\%20\%284_13_18\%29_.pdf.

33. Pollicino 0. The Right to Internet Access: Quid Iuris? The Cambridge Handbook of New Human Rights: Recognition, Novelty, Rhetoric / eds. In A.Von Arnauld, K. Von der Decken, M. Susi. Cambridge : Cambridge University Press, 2020. P. 263-275. DOI: 10.1017/9781108676106.021.

34. Posenato $\mathrm{N}$. The protection of the right to freedom of expression: a panorama of the Inter-American Court of Human rights Case Law. Espaço Jurídico Journal of Law. 2016. February. P. 51-68. DOI:10.18593/ejjl.v16i3.9770.

35. Salau Aaron Olaniyi. The right of access to information and national security in the African regional human rights system. African Human Rights Law Journal. 2017. Vol.17, No.2. URL: http://www.scielo.org.za/scielo.php?script=sci_arttext\&pid=S1996$20962017000200003 \#$ back_fn63.

36. Twentieth anniversary Joint Declaration: Challenges to freedom of expression in the next decade. 2019. URL: https://www.ohchr.org/Documents/Issues/Opinion/JointDeclaration 10July2019_English.pdf. 